\title{
Anna Machnikowska, Prawo własności w Polsce w latach 1944-1981. Studium historycznoprawne, Wydawnictwo Uniwersytetu Gdańskiego, Gdańsk 2010, 626 stron
}

Wydawnictwo Uniwersytetu Gdańskiego oddało w ręce czytelników potężny objętością tom o prawie własności w Polsce w czasach komunistycznych, autorstwa Anny Machnikowskiej. Autorka jest znaną specjalistką niedawnej historii prawa, zwłaszcza okresu Polski Ludowej. Pisywała dotychczas głównie o prawie karnym oraz funkcjonowaniu wymiaru sprawiedliwości w sprawach karnych, a nie tak dawno opublikowała niemal równie wielki objętością (550 stron) i zakresem poruszanych tematów tom pt. Wymiar sprawiedliwości w Polsce w latach 1944-1950 (Wyd. UG, Gdańsk 2008).

Prawo własności to fundament całego prawa cywilnego, a nawet więcej - całego prawa prywatnego. Zagadnienie własności to ważny problem ustrojowy, a więc także ideologiczny. Właśnie w systemie komunistycznym zagadnienie własności stało się przede wszystkim problemem ideologicznym, o korzeniach sięgających samych źródeł ideologii socjalistycznej/komunistycznej, sięgających czasów, kiedy nawet Marks był jeszcze w kołysce. Wszak to socjaliści utopijni rzucili myśl likwidacji własności prywatnej.

Manifest komunistyczny, najważniejszy dokument programowy komunizmu, opublikowany jeszcze w połowie XIX w. (1848) przez Marksa i Engelsa, jako najważniejsze wskazanie zawierał zniesienie własności prywatnej, co miało nastąpić po zwycięstwie rewolucji proletariackiej. Pisali oni: „Proletariusze nie mają nic własnego do zabezpieczenia, muszą natomiast zburzyć wszystko, co dotychczas zabezpieczało i ochraniało własność prywatną" ${ }^{1}$. Myśl ta powtarzana była stale w programach komunistów. Manifest komunistyczny podsumowywał: „komuniści mogą zawrzeć swą teorię w jednym zwrocie: zniesienie własności prywatnej”2.

Wywody Marksa i Engelsa nie zawierały analizy konsekwencji prawnych likwidacji własności prywatnej, nie mieli ku temu fachowego przygotowania ${ }^{3}$. Uwagi Marksa i Engelsa na temat prawa miały charakter zupełnie incydentalny. Zajmowali się stosunkami ekonomicznymi w kapitalizmie czasów, w których żyli i z autopsji znali. Sami też zmieniali poglądy; Marksowskie określenia własności nawet w kategoriach ekonomicznych były zmienne i niekonsekwentne ${ }^{4}$. Marks ani Engels nie przewidywali, że w miejsce własności prywatnej pojawi się własność państwa ${ }^{5}$, a to nie będzie to samo, co własność społeczeństwa.

$1 \quad$ K. Marks, F. Engels, Manifest komunistyczny, s. 74 i passim.

2 Ibidem, s. 78.

3 A. Lityński, Prawo Rosji i ZSRR 1917-1991 czyli historia wszechzwiązkowego komunistycznego prawa (bolszewików). Krótki kurs, Warszawa 2010, s. 212. M. Bednarek, Przemiany własności w Polsce. Podstawowe koncepcje i konstrukcje normatywne, Warszawa 1994, s. 25. 
W PRL konstytucja z 1952 r. ostatecznie - na czas istnienia PRL - zerwała z jednolitym ujmowaniem własności, odróżniając różne formy własności:

1) społeczną: ogólnonarodową lub spółdzielczą;

2) indywidualną, czyli prywatną: drobnotowarową lub kapitalistyczną;

3) osobistą (art. 8-13).

Była to wierna kopia konstrukcji i rozwiązań radzieckich ${ }^{6}$, podobnie jak cała konstytucja brała wzór z konstytucji stalinowskiej $1936 \mathrm{r}$.

Pojęcie własności pojawiało się w konstytucji wielokrotnie i stawiane było przez ustawodawcę jako problem społeczno-gopodarczo-polityczny. Konstytucja uznawała własność społeczną za fundamentalną instytucję tak zwanej nadbudowy prawnej, w ogóle za fundament ustroju gospodarczego, społecznego i politycznego. Artykuł 77 konstytucji nakładał na każdego obywatela obowiązek strzeżenia własności społecznej. Ponadto obowiązek ochrony własności społecznej konstytucja nakładała na rady narodowe (art. 39), na Prokuratora Generalnego (art. 54 ust. 1), a także na sądy, które „stoją na straży ustroju Polskiej Rzeczypospolitej Ludowej, ochraniają zdobycze polskiego ludu pracującego, strzegą praworządności ludowej, własności społecznej i praw obywateli, karzą przestępców” (art. 48).

Realizacja nowych zasad w prawie cywilnym wymagała przebudowy całego prawa cywilnego ${ }^{7}$. O tym właśnie traktuje monografia Anny Machnikowskiej. Zamierzenie było ogromne, jak wielkie przekształcenia zaszły w prawie cywilnym w Polsce Ludowej. Można mieć jedynie wątpliwości, czy dostateczne uzasadnienie ma data zakończenia obserwacji przez Autorkę - rok 1981. Nie widzę, by coś się wówczas zdarzyło dość ważnego dla zmian we własności, czy prawie własności w Polsce. Jest to data niewątpliwie ważna dla zmian w świadomości społeczeństwa polskiego, ale nie widzę uzasadnienia dla uznania jej za etap w dziejach prawa własności w PRL. Skłonny jestem sądzić, że Autorka, przytłoczona ogromem materiału swojej wielkiej pracy, chciała zakończyć już swoje dzieło. Uważam, że miała do tego prawo: obszar merytoryczny i zakres chronologiczny pracy jest i tak wręcz olbrzymi.

Z punktu widzenia historyka prawa (a bardziej historyka niż prawnika) najciekawszy jest rozdział I pracy. Ten ogromny (jak niemal wszystko u Autorki) rozdział składa się z dwóch części. Najpierw przedstawione zostały ideologiczne podstawy nowych koncepcji w zakresie prawa własności; sięgają one - oczywiście - Marksa oraz Lenina i Stalina. Następnie w nader ciekawy sposób Autorka zaprezentowała adaptację tych zasad w Polsce Ludowej w całym okresie 1944-1981; jest to bardzo ładne powiązanie problemów prawnych z wydarzeniami historyczno-politycznymi owych czasów. Rozdział II to analiza przekształceń stosunków własnościowych w latach bezpośrednio powojennych; jest tu nie tylko reforma rolna i nacjonalizacja mienia pozarolniczego, lecz także zagadnienia mienia poniemieckiego i opuszczonego, znajdującego się w posiadaniu

6 A. Lityński, op. cit., s. 220.

7 Idem, Historia prawa Polski Ludowej, Warszawa 2010. 
Armii Czerwonej, sprawy osadników. Konstytucyjne zagadnienia prawa własności, jak też ewolucja treści prawa własności w prawie cywilnym i prawnokarna ochrona prawa własności - to sprawy zawarte w rozdziale III. Tytuł rozdziału IV wydaje mi się być nieco udziwniony w stosunku do jego zawartości, ale wyeksponowane w nim zostały m.in. specyficzne kwestie z zakresu własności nieruchomości rolnych, własności domów i lokali, i inne.

Całość niezmiernie dokładnej analizy prawa wsparta została bogatą bazą źródłową, a przeprowadzona nader skrupulatnie. Jak wspomniano, ładnie umieszczono rozważania na tle wydarzeń politycznych. Otrzymaliśmy cenne dzieło, które musi się stać lekturą obowiązkową każdego historyka prawa, z dużą korzyścią dla naszej wiedzy o kilkudziesięciu latach Polski Ludowej. 